
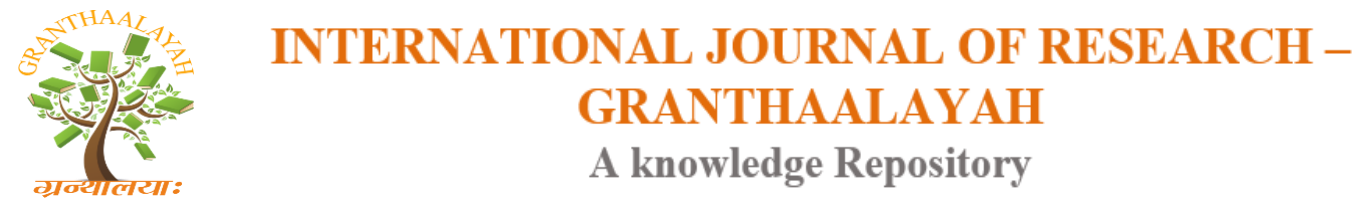

Science

\title{
EFFECT OF FARM YARD MANURE APPLICATION RATE ON YIELD AND YIELD COMPONENTS OF LETTUCE (LACTUCA SATIVA) AT JIMMA SOUTHWESTERN ETHIOPIA
}

\author{
Wendimu Melese ${ }^{* 1}$ \\ *1 Jimma University, College of Agriculture and Veterinary Medicine, Department of \\ Horticulture and Plant Science, P.O.Box. 307, Jimma, ETHIOPIA
}

DOI: https://doi.org/10.29121/granthaalayah.v4.i8.2016.2565

\section{ABSTRACT}

The current study was conducted at Jimma University College of Agriculture and Veterinary Medicine of Ethiopia to find the effect of farm yard manure application rate on yield and yield component of lettuce. The experiment was arranged at three levels of farm yard manure (5 ton/ha, 10 ton/ha and 15 ton/ha). Each treatment was arranged as $1.1 \mathrm{~kg}, 2.25 \mathrm{~kg}$ and 3.3 $\mathrm{kg} / 1.5 \mathrm{~m} 2 \mathrm{as} \mathrm{T} 2, \mathrm{T3}$ and $\mathrm{T} 4$ respectively, and the control $(0 \mathrm{~kg} / 1.5 \mathrm{~m} 2)$ as $\mathrm{T1}$. A total of four treatments have been used. As the experimental tests showed that, farm yard manure with the rate of $3.3 \mathrm{~kg}$ (15 ton/hek) is highly increased the yield and yield components of lettuce (plant height, leaf size, number of leaf per plant, fresh leaf weight, root depth and number of root per plant. Hence, it is recommended for general cultivation of lettuce under Jimma growing condition. Moreover, as the crop is growing at small scale farmer's level in Jimma area further studies are needed with regard to the improvement of agronomic practices for lettuce at commercial level cultivation in Jimma and similar agro ecology.

Keywords:

Farm yard manure, treatment, application rate, lettuce.

Cite This Article: Wendimu Melese, "EFFECT OF FARM YARD MANURE APPLICATION RATE ON YIELD AND YIELD COMPONENTS OF LETTUCE (LACTUCA SATIVA) AT JIMMA SOUTHWESTERN ETHIOPIA" International Journal of Research - Granthaalayah, Vol. 4, No. 8 (2016): 75-83.

\section{INTRODUCTION}

\section{BACKGROUNDS AND JUSTIFICATION}

Prior to the nineteenth century, fresh and composted manure were among the primary tools employed to maintain agricultural soil fertility (Martin and Gershuny, 1992). In the mid 1800's, Justus von Liebig and others proposed that mineral salts replace organic amendments as the source of essential plant nutrients needed for agricultural production (Brock, 1997). This new 
emphasis on chemistry, and the industrialization of agriculture in America and Europe through the first half of the20thcentury, brought with it a reduced emphasis on the use of manure and organic matter to sustain soil fertility (Howard, 1943). Application of organic amendments such as compost and farm yard manure, have been demonstrated to be effective tools to manage soil fertility in vegetable production (Roe, 1998; Verma, 1995). These amendments not only supply essential plant nutrients to a crop, but by virtue of their organic fraction can improve the nutrient holding capacity of soils, nutrient availability, beneficial soil microorganism activity, soil structure, and plant growth in acid soils (Marchensini et al.,1988; Woomer et al. 1994; Marcus et al., 1995; Hue and Sobieszczyk, 1999). In addition to these effects on crop production, utilization of farm yard manure and compost in vegetable systems in Hawaii provides an opportunity to reduce the amount of inputs (i.e. fertilizers) needed to be brought into the State. Maximum use of locally available resources is an integral part of sustainable vegetable production in the tropics (Valenzuela, 2000), and composting provides an opportunity to recycle materials that would otherwise add to the amount of 2 waste needing disposal. In fact, recycling is one of the primary reasons cited by growers for substituting organic fertilizers for their synthetic counterparts (Wallace, 1994)

Lettuce is the common term for any plants of the genus Lactuca of the flowering plant family Asteraceae (or, alternatively, Compositae), and especially refers to plants of the commercially important species Lactuca sativa. The term lettuce also is used to refer to the edible, succulent leaves of $L$. sativa, which commonly are eaten raw in salads, but also may be eaten cooked. $L$. sativa is the most commonly used salad vegetable (Katz and Weaver 2003). Lettuce provides values for the ecosystem and for humans. Ecologically, the wild and cultivated forms of lettuce provide food for diverse animals, including insects (such as the larvae of some Lepidoptera), rabbits, and deer. Thus, the lettuce plants are foundational for food chains. In terms of humans, the cultivated lettuce plants are eaten, whether cold and raw as typical in some countries (in salads, hamburgers, etc.) or cooked as typical in countries such as China. Although generally considered a poor source of nutrients, lettuce does provide many of the same nutrients as other green vegetables, albeit mostly in smaller amounts (Katz and Weaver 2003). Its low calories make it a popular diet food. There also is some medicinal use attributed to lettuce, including ingredients considered useful as a sleep inducer and sedative. There are hundreds of varieties of lettuce (Lactuca sativa), and since they peak at different times of the year, production of lettuce for salads continues year round (Herbst 2001). There are generally four main groups of cultivars, based on head formation and leaf structure: head lettuce (L. sativa var. capitata), which can be divided further into butter head and crisp head (iceberg); romaine or cos lettuce (L. sativa var. longifolia); stem or asparagus lettuce (L. sativa var. asparagina); and leaf lettuce (L. sativa var. crispa). Herbst (2001) recognizes as the four general lettuce classifications butter head, crisphead,', leaf, and romaine, omitting the stem or asparagus lettuce.

Ethiopia faces a wider set of soil fertility issues beyond chemical fertilizer use, which has historically been the major focus for extension workers, researchers, policymakers, and donors. If left un-checked, this wider set of issues will limit future output and growth in agriculture across the country; in some areas, they already limit the effectiveness of chemical fertilizer. These chemical, physical, and biological issues interact and include loss of organic matter, macronutrient, and micronutrient depletion, topsoil erosion, acidity, salinity, and deterioration of other physical soil properties. In addition, Ethiopia has soil types with inherent characteristics 
which can be problematic for crop production and which need special management. According to IFPIR (2010) the main reasons of organic matter depletion in the country, returning animal dung and crop residues to soil and excessive tillage, among others.

Farm yard manure utilization is well known throughout the country as it is available everywhere on the place which known with high cattle raring. According to FAO (http://faostat3.fao.org/browse/Q/QA/E Ethiopia found at 5th rank in the world with 54,000,000 total cattle number in the country. However even though resources are like this, the write level of FYM at small scale and commercial level is still unknown. As a result this research works is trying to recommend the write amount of FYM for specific areas which is being listed at the title part of the paper.

\section{MATERIALS AND METHODS}

\section{DESCRIPTION OF EXPERIMENTAL SITE}

The experimental site was arranged in college of agriculture and veterinary medicine, Horticulture department research farm. JUCAVM was geographically located $335 \mathrm{~km}$ south west of Addis Ababa at about 7o, 33N latitude and 36o, 57'E longitude at an altitude of 1700m.a.s.1. The mean maximum and minimum temperature were $28.8 \mathrm{oc}$ and $11.4 \mathrm{oc}$ respectively and the mean maximum and minimum relative humidity were $91.4 \%$ and $39.92 \%$ respectively. The mean rain fall of the area was $1500 \mathrm{~mm}$. ( Fikadu, 2015).

\section{METHOD OF DATA COLLECTION AND EXPERIMENTAL DESIGN}

The experiment was followed by a complete randomized block design (RCBD) with four treatments, each replicated three times. All data has been subjected to analysis of variance (ANOVA) using SAS statistical software version 9.1. Error and mean was also compared using least significant different (LSD) at the alpha 0.05 probability level.

The experiments was managed at three levels of farm yard manure (5 ton/ha, 10 ton/ha and 15 ton/ha). Each treatment was arranged as $1.1 \mathrm{~kg}, 2.25 \mathrm{~kg}$ and $3.3 \mathrm{~kg} / 1.5 \mathrm{~m}^{2}$ as T2, T3 and T4 respectively, and the control $\left(0 \mathrm{~kg} / 1.5 \mathrm{~m}^{2}\right)$ as T1. A total of four treatments have been used. The site was cleared manually, ploughed and weeded before seedbeds were marked and demarcated. There was twelve seedbeds each measuring $1.5 \times 1.5 \mathrm{~m}$ and was separated by a buffer of $0.5 \mathrm{~m}$. The distance between blocks then was 1 meter. Seedbeds have been leveled using hand tools to provide a medium fine tilt for the growth of the lettuce crop. The farm yard manure was applied to seedbeds and mixed with soil per treatment requirement. The selected variety of lettuce for this research was loose leaf seeds has been sown on prepared plots directly and immediately mulched with locally available mulching materials and water has been given artificially. The inter row spacing of $40 \mathrm{~cm}$ and intra row spacing of $30 \mathrm{~cm}$ has been. After the germination start then immediately mulched materials was removed and after 10 followed days the thinning activities has been done. 


\section{DATA COLLECTED}

When the time for harvesting is reached, all matured lettuce was harvested one by one and the measurements have been taken with ruler and graph paper for plant height and leaf size data's. And for leaf weight the researcher utilized sensitive valance and have been taken the right weight of each sample plant (Wood and Roper, 2000).

1) Plant height: The height of the main plant from the border of the soil to the top of the main plant stem was measured with meter.

2) Leaf size: Trace the leaves on graph paper and count the squares covered to give us an estimate of the surface area for each leaf has been done. Repeating this for each leaf on a plant and for each plant in the experiment has been done.

3) Number of leaf per plant: The number of roots of each plant was counted by the research team. Every visible root attached below the main stem of the plant, was counted. Placing the plant over some graph paper to avoid counting errors has been done.

4) Fresh leaf weight: The leaf was removed from the base of petiole and washed off any loose soil. Blotting the plants gently with soft paper towel to remove any free surface moisture has been done. Weigh immediately (plants have a high composition of water, so waiting to weigh them may lead to some drying and therefore produce inaccurate data).

5) Root depth: The depth of the main root from the border of the soil to the tip of the main plant root was measured with meter.

6) Number of roots per plant: The number of roots of each plant was counted by the research team. Every visible root attached below the main stem of the plant, was counted. Placing the plant over some graph paper to avoid counting errors has been done.

\section{DATA ANALYSIS}

The data collected in the experiment were statistically analyzed with SAS Version 9.0 statistical software program. Analysis of variance (ANOVA) was done on every measured parameter to determine the significance of differences between means of treatments. Means for each parameter were separated by the least significant difference (LSD) at 5\% level of significance (Gomez and Gomez, 1984).

\section{RESULT AND DISCUSSION}

\section{EFFECTS OF FARM YARD MANURE APPLICATION RATE ON PLANT HEIGHT OF LETTUCE}

After the experiment have been done the variation between the rates of farm yard manure in contrasting with each of the treatment was became visible. Among the treatments given, treatment $4(3.3 \mathrm{~kg}) /(15$ ton $/$ hek $)$ (20.3333) was with the most significance difference at 0.05 probability level as compared to the rests. And followed by $2.25 \mathrm{~kg}) /(10$ ton/hek) (19) (Table1). S. Detpiratmongkol I (2014) confirmed Plant height and stem 478dry weight increased with increasing rates of organic manure. This is may be because of the higher nitrogen in the manure can trig vegetative growth of the plant. 
Table 1: Effects of farm yard manure application rate on plant height

\begin{tabular}{llll}
\hline t Grouping & Mean & $\mathrm{N}$ & Trt \\
\hline A & 20.3333 & 3 & 4 \\
A & & & \\
A & 19.0000 & 3 & 3 \\
B & 16.3333 & 3 & 2 \\
B & 2.0000 & 3 & \\
\hline P.V 0.005 & & & \\
C.V (\%) & 6.768622 & & \\
LSD & 2.2088 & & \\
\hline
\end{tabular}

C.V: Coefficient of Variance; LSD: Least Significant Difference; Trt: Treatments

Means with the same letter are not significantly different.

\section{EFFECTS OF FARM YARD MANURE APPLICATION RATE ON LEAF SIZE OF LETTUCE}

Among the treatments given to test the effects farm yard manure application rate on leaf size of lettuce, treatment $4,(3.3 \mathrm{~kg}) /(15 \mathrm{ton} / \mathrm{hek})$ was recorded with a maximum leaf size of lettuce (248.33) which was statically higher than other lower levels. And followed by $2.25 \mathrm{~kg}) /(10$ ton/hek) (236.33). Between each treatment also there was significance different at 0.05 confidence level (table 2$)$. The leaf area was significantly $(\mathrm{p}<0.05)$ higher in lettuce provided with chicken manure at $60 \mathrm{t} / \mathrm{ha}$ and lowest in plants applied with chemical fertilizer Michael $\mathrm{T}$ et al (2012). It could be because of soil organic matter can provide the following function to the crops, it increases soil fertility as it retains cations and conserves nutrients in organic forms and slowly releases required nutrients for plant uptake and growth, it binds soil particles together; the cementing and aggregation functions improving soil structure and aeration, it acts as a sponge in the soil, retaining soil moisture and soils with high organic matter content can hold more water than those low in organic matter, it provides food for micro-organisms living in the soil which are the reasons of vigor leafy crops $\mathrm{FAO}(2000)$.

Table 2: Effects of farm yard manure application rate on leaf size

\begin{tabular}{llll}
\hline t Grouping & Mean & $\mathrm{N}$ & Trt \\
\hline & & & \\
A & 248.000 & 3 & 4 \\
B & 236.333 & 3 & 3 \\
C & 225.333 & 3 & 2 \\
D & 125.333 & 3 & 1 \\
\hline P.V 0.005 & & & \\
C.V $(\%)$ & 1.467992 & & \\
LSD & 6.1246 & & \\
\hline
\end{tabular}

C.V: Coefficient of Variance; LSD: Least Significant Difference; Trt: Treatments

Means with the same letter are not significantly different. 
EFFECTS OF FARM YARD MANURE APPLICATION RATE ON NUMBER OF LEAF PER PLANT OF LETTUCE

Among the treatments given $3.3 \mathrm{~kg}, 2.25 \mathrm{~kg}, 1.1 \mathrm{~kg}$ and control; the significant difference was obtained between treatment $4(3.3 \mathrm{~kg})$, treatment $2(1.1 \mathrm{~kg})$ and treatment 1 (control). But between treatment $4(3.3 \mathrm{~kg})$ and treatment $2(2.25)$ there was no significance difference on number of leaf per plant (table 3) treatment 4 was recorded with maximum mean value of 19.33 and followed by $14.000(1.1 \mathrm{~kg})$ (treatment 3$)$

Table 3: Effects of farm yard manure application rate on Number of leaf per plant

\begin{tabular}{llll} 
t Grouping & Mean & N & Trt \\
\hline A & 19.333 & 3 & 4 \\
A & & & \\
A & 17.333 & 3 & 2 \\
B & 14.000 & 3 & 1 \\
C & 10.000 & 3 & \\
\hline P.V 0.005 & & & \\
C.V $(\%)$ & 10.82292 & & \\
LSD & 3.2795 & & \\
\hline
\end{tabular}

C.V: Coefficient of Variance; LSD: Least Significant Difference; Trt: Treatments Means with the same letter are not significantly different.

\section{EFFECTS OF FARM YARD MANURE APPLICATION RATE ON FRESH LEAF WEIGHT OF LETTUCE}

Among the treatments given to test the effects on fresh leaf weight of lettuce, treatment 4, $(3.3 \mathrm{~kg}) /(15 \mathrm{ton} / \mathrm{hek})$ was recorded with a maximum fresh leaf weight $(384.33 \mathrm{gm})$ of lettuce as compared to the rests. And followed by (283.66gm) $(2.25 \mathrm{~kg}$ farm yard manure $) /(10 \mathrm{ton} / \mathrm{hek})$ and treatment2 $(266.67 \mathrm{gm})$. Between each treatment also there was significance different at 0.05 confidence level (table 4) But between treatment $3(2.25 \mathrm{~kg})$ and treatment $2(1.1 \mathrm{~kg})$ there was no significance difference.

Table 4: Effects of farm yard manure application rate on Fresh leaf weight

\begin{tabular}{llcc}
\hline t Grouping & Mean & N & Trt \\
\hline A & 384.333 & 3 & 4 \\
B & 283.667 & 3 & 3 \\
B & & & \\
B & 266.67 & 3 & 2 \\
C & 208.33 & 3 & \\
\hline P.V 0.005 & & & \\
C.V (\%) & 25.898 & & \\
LSD & 3.2795 & & \\
\hline
\end{tabular}

C.V: Coefficient of Variance; LSD: Least Significant Difference; Trt: Treatments

Means with the same letter are not significantly different. Source: own experiment 


\section{EFFECTS OF FARM YARD MANURE APPLICATION RATE ON ROOT DEPTH}

Among the treatments given to test the effects on Root depth of lettuce, treatment $4,(3.3 \mathrm{~kg}) /(15$ ton/hek) was recorded with a maximum Root depth $(13 \mathrm{~cm})$ of lettuce as compared to the rests. And followed by $(10 \mathrm{~cm})(2.25 \mathrm{~kg}) /(10 \mathrm{ton} / \mathrm{hek})$. Between treatment 4 and 3 as well as between treatment 2 and 1 there was significance difference at 0.05 confidence level (table 5) But between treatment $3(1.1 \mathrm{~kg})$ and treatment $2(1.1 \mathrm{~kg})$ there was no significance difference.

Table 5: Effects of farm yard manure application rate on Root depth

\begin{tabular}{lccc}
\hline t Grouping & Mean & $\mathrm{N}$ & Trt \\
\hline A & 13.000 & 3 & 4 \\
B & 10.000 & 3 & 3 \\
B & & 3 & 2 \\
B & 9.3333 & 3 & 1 \\
C & 6.3333 & & \\
\hline P.V 0.005 & 10.48752 & & \\
C.V $(\%)$ & 2.0255 & & \\
LSD & & & \\
\hline
\end{tabular}

C.V: Coefficient of Variance; LSD: Least Significant Difference; Trt: Treatments

Means with the same letter are not significantly different.

EFFECTS OF FARM YARD MANURE APPLICATION RATE ON NUMBER OF ROOT PER PLANT

Among the treatments given to test the effects on number of root per plant of lettuce, treatment 4 , $(3.3 \mathrm{~kg}) /(15 \mathrm{ton} / \mathrm{hek})$ was recorded with a maximum number of roots per plant (11.667) of lettuce as compared to the rests. And followed by (10.667) $(2.25 \mathrm{~kg}) /(10$ ton/hek). But between treatment $4(3.3 \mathrm{~kg}) /(15 \mathrm{ton} / \mathrm{hek})$ and $3(2.25 \mathrm{~kg}) /(10 \mathrm{ton} / \mathrm{hek})$ there was significant different at 0.05 confidence level (table 4) But between treatment $4(3.3 \mathrm{~kg}) /(15$ ton $/$ hek $)$ and treatment3 $(2.25 \mathrm{~kg}) /(10 \mathrm{ton} / \mathrm{hek})$ as well as between treatment $2(1.1 \mathrm{~kg})$ and treatment 1 there was no significance difference among the rates of farm yard manure application (Table 6).

Table 6: Effects of farm yard manure application rate on number of root per plant

\begin{tabular}{|c|c|c|c|c|}
\hline \multicolumn{2}{|c|}{ t Grouping } & Mean & & Trt \\
\hline & $\begin{array}{l}\text { A } \\
\text { A }\end{array}$ & 11.667 & 3 & 4 \\
\hline $\begin{array}{l}\text { B } \\
\text { B }\end{array}$ & A & 10.667 & 3 & 3 \\
\hline B & $\begin{array}{l}\mathrm{C} \\
\mathrm{C}\end{array}$ & 9.000 & 3 & 2 \\
\hline & $\mathrm{C}$ & 7.667 & 3 & 1 \\
\hline
\end{tabular}


P.V 0.005

C.V $(\%)$

LSD

C.V: Coefficient of Variance; LSD: Least Significant Difference; Trt: Treatments

Means with the same letter are not significantly different.

\section{CONCLUSION AND RECOMONDATION}

These amendments not only supply essential plant nutrients to the crop, but by virtue of their organic fraction can improve the nutrient holding capacity of soils, nutrient availability, beneficial soil micro-organism activity, soil structure, and plant growth in acid soils

Application of organic amendments such as compost and farm yard manure, have been demonstrated to be effective tools to manage soil fertility in vegetable production. As the experimental tests showed that, farm yard manure with the rate of $3.3 \mathrm{~kg}$ ( 15 ton/hek) is highly increased the yield and yield components of lettuce (plant height, leaf size, number of leaf per plant, fresh leaf weight, root depth and number of root per plant.

\section{ACKNOWLEDGEMENT}

My first and deepest gratitude goes to God, who gives me the patience and courage for the completion of this work. Next to this, I would like to convey a grateful thanks to my advisor Gebre medihin for his unsaved advice, comment, and suggestion. I would like also to express my thanks to the Jimma University College of Agriculture and Veterinary Medicine library computer centre for their cooperation and willingness to provide the available materials.

\section{REFERENCES}

[1] Baldwin, I. T. and P. Callahan. 1993. Autotoxity and chemical defense: Nicotine accumulation and carbon gain in solanaceous plants. Oecologia. 94: 534-541.

[2] Bender, D. A., and A. E. Bender. 2005. A Dictionary of Food and Nutrition. New York: Oxford University Press.

[3] Brookes, P.C. 1995. The use of microbial parameters in monitoring soil pollution by heavy metals, Biol. Fertil. Soils. 19: 269-279

[4] Cuvardic M., Tveitnes S., Krogstad T., Lombnaes P. (2004): Long-term effects of crop rotation and different fertilization systems on soil fertility and productivity. Acta Agric. Scand., Soil and Plant Sci. 54:193-201.

[5] Cuvardic M., Seremesic S., Novakovic N. (2006): Soil Fertility in Organic Farming in the First Years After Transition. Paper presented at Joint Organic Congress, Odense, Denmark, May 30-31, 2006 (http//orgprints.org/7362/).

[6] FAO corporate document repository(2000), the importance of soil organic matter, natural resource management and environment department

[7] Fikadu Negese Bir(2015), Effect of Spacing and Nitrogen Fertilizer on the Yield and Yield Component of Shallot (Allium ascalonium L.), Journal of Biology, Agriculture and Healthcare, Vol.5,Pp 84. 
[8] Herbst, S. T. 2001. The New Food Lover's Companion: Comprehensive Definitions of Nearly 6,000 Food, Drink, and Culinary Terms. Barron's Cooking Guide. Hauppauge, NY: Barron's Educational Series.

[9] International food policy research institute, fertilizer and soil fertility potential in Ethiopia, constraints and opportunities for enhancing the system, supported by CGIAR pp,11-12.

[10] http://chestofbooks.com/gardening-horticulture/Commercial-Gardening-1/Value-OfFarmyard-Manure.html\#ixzz4BSv2qfnO

[11] http://www.sciencebuddies.org/science-fair projects/project_ideas/PlantBio_measuring_growth.shtml

[12] Judd, W. S., C.S. Campbell, E. A. Kellogg, and P. F. Stevens. 1999. Plant Systematics: A Phylogenetic Approach. Sunderland, MA: Sinauer Associates

[13] Katz, S. H and W. W. Weaver. 2003. Encyclopedia of Food and Culture. New York: Schribner

[14] Managing Farmyard Manure for the Greatest Value, http://www.stackyard.com/news/2009/04/fertiliser/01_eblex_farmyard_manure.html)

[15] Michael T. Masarirambi, Bekhumusa M. Mbokazi, Paul K. Wahome and Tajudeen O. Oseni, Effects of Kraal Manure, Chicken Manure and Inorganic Fertilizer on Growth and Yield of Lettuce ( Lactuca sativa L. var Commander) in a Semi-arid Environment Horticulture Department, University of Swaziland, P.O. Luyengo, M205, Swaziland, Pp 58-62.

[16] Nshimiyimana Mathieu (2012), Effect Of Organic and Mineral Fertilizers On Growth And Yield Of Beet Crop (Beta Vulgaris),Pp 17-18

[17] Nur OKUR*, Hüseyin Hüsnü KAYIKÇIO/LU, Bülent OKUR, Sezai DEL‘BACAK (2007), Department of Soil Science, Faculty of Agriculture, Ege University, Bornova, «zmir TURKEY

[18] Phenmedipham, Desmedipham, and Cycloate Impact Weed Control in Red Beets? Progress Report submitted to NE-PIAP and NAPIAP. Dept. Fruit and Vegetable Sciences, Cornell University. 2002

[19] Tamimi, Y., J. A. Silva, R. S. Yost, and N. V. Hue. 1994. Adequate nutrient levels in soils and plants in Hawaii. Fact Sheet no. 3. CTAHR.

[20] Wood, A.J. and Roper, J. (2000). "A Simple and Nondestructive Technique for Measuring Plant Growth and Development." American Biology Teacher, v62 n3 p215-17. 